SOI: $1.1 /$ TAS DOI: $10.15863 /$ TAS

International Scientific Journal Theoretical \& Applied Science

p-ISSN: 2308-4944 (print) e-ISSN: 2409-0085 (online)

Year: $2018 \quad$ Issue: $01 \quad$ Volume: 57

Published: $30.01 .2018 \quad$ http://T-Science.org

SECTION 33. Advertising technologies. Creative. Innovations.
Dmitry Olegovich Bordukh bachelor, Institute of Entrepreneurship and Sevice sector (branch) DSTU, g. Shakhty

Maria Valeryevna Reva the Department of "Private animal husbandry and feeding of farm animals" "Don state agrarian University" in the village of Persianovka, Rostov region

Vladimir Timofeevich Prokhorov Department of "Design,technology, and design" Institute of service sector and entrepreneurship in Shakhty, Rostov region

Stanislav Matveyevich Zverev JSC "Roslegprom" in city Moscow

Natalia Vasilievna Tikhonov "Construction of clothes and shoes" Kazan National Research Technological University (Kazan, Republic of Tatarstan, Russia)

\title{
ABOUT SEARCH OF MOTIVATION ON EFFICIENT MANAGEMENT OF COLLECTIVES OF ENTERPRISES FOR MANUFACTURE OF THE PRODUCT DEMANDED BY THE MARKET OF DEMAND WITH THE GUARANTEE OF RECEIVING SUSTAINABLE TYPE FROM THEIR ACTIVITY
}

\footnotetext{
Abstract: In the article the authors first explored the possibilities of human motivation in his effective management of the staff of the enterprise of light industry for making them in demand and import-substituting products in the market demand given its attractiveness and ensuring the company's sustainable TEP from its activities. Of course, it will be possible, if the decision on the formation of innovative technological processes will be based on creating conditions for effective manufacture of all assortment of shoes with the price niche in its broad range.

Key words: market, demand, consumer, producer, real quality, promotional quality, import substitution, demand, competitiveness, product range, footwear, attractiveness of the product.

Language: Russian

Citation: Bordukh DO, Reva MV, Prokhorov VT, Zverev SM, Tikhonov NV (2018) ABOUT SEARCH OF MOTIVATION ON EFFICIENT MANAGEMENT OF COLLECTIVES OF ENTERPRISES FOR MANUFACTURE OF THE PRODUCT DEMANDED BY THE MARKET OF DEMAND WITH THE GUARANTEE OF RECEIVING SUSTAINABLE TYPE FROM THEIR ACTIVITY. ISJ Theoretical \& Applied Science, 01 (57): 272-292.

Soi: http://s-o-i.org/1.1/TAS-01-57-44 Doi: crostef https://dx.doi.org/10.15863/TAS.2018.01.57.44

UDC 335.17:519.78

\section{О ПОИСКАХ МОТИВАЦИИ ПО ЭФФЕКТИВНОМУ УПРАВЛЕНИЮ КОЛЛЕКТИВАМИ ПРЕДПРИЯТИЙ ДЛЯ ИЗГОТОВЛЕНИЯ ИМИ ВОСТРЕБОВАННОЙ НА РЫНКАХ СПРОСА} ПРОДУКЦИИ С ГАРАНТИЕЙ ПОЛУЧЕНИЯ УСТОЙЧИВЫХ ТЭП ОТ ИХ ДЕЯТЕЛЬНОСТИ

Аннотация: в статье авторы впервые исследовали возможности мотивации человека по его эффективному управлению коллективом предприятия легкой промышленности для изготовления им востребованной и импортозамещаемой продукции на рынке спроса с учетом ее привлекательности и гарантируя предприятие устойчивое ТЭП от их деятельности. Конечно, это будет возможным, если само решение по формированию инновационных технологических процессов будет основано на создании условий по эффективному изготовлению всего ассортиментного ряда обуви с ценовой нишей в широком ее диапазоне.
} 
Ключевые слова: рынок, спрос, потребитель, производитель, реальное качество, рекламное качество, импортозамещение, востребованность, конкурентоспособность, ассортиментный ряд, обувь, привлекательность товара.

\section{Введение}

Не существует ни одного предприятия, которое не имело бы внешнего окружения и не находилось бы с ним в состоянии постоянного взаимодействия. Любое предприятие нуждается в регулярном получении из внешней среды исходных продуктов для обеспечения своей жизнедеятельности. При этом каждое предприятие должно отдавать что-то во внешнюю среду в качестве компенсации за ее существование. Как только рвутся связи с внешней средой, предприятие погибает. В последнее время в связи с усилением и усложнением конкуренции, а также резким ускорением процессов изменения в окружающей среде предприятия всё в большей мере вынуждены уделять внимание вопросам взаимодействия с окружением, всё в большей мере развивать способности адаптации к изменениям внешней среды.

Ключевую роль в выработке и проведении политики взаимодействия предприятия с окружением играет менеджмент, особенно его верхний уровень. Вопросы долгосрочной стратегии взаимодействия предприятия со средой становятся во главу угла построения всех процессов управления. Менеджмент уже не занимается только внутренними вопросами предприятия. В равной, а может быть и в большей мере его взор направлен за пределы предприятия. Менеджмент старается строить эффективное взаимодействие предприятия с окружением не только путем воздействия на процессы, происходящие в предприятии, но и путем воздействия на окружающую среду.

\section{Основная часть}

Стратегическое управление, решающее эти задачи, выдвигается на первый план в комплексе процессов управления предприятием. Внешнее окружение предприятия, состояние взаимодействия с которым определяется преимущественно качеством управления им, можно представить в виде двух сфер.

Первая сфера - это общее внешнее окружение предприятия. Данное внешнее окружение отражает состояние общества, его экономики, природной среды и не связано непосредственно с конкретным, предприятием. Общее внешнее окружение является более или менее одинаковым для подавляющего большинства предприятий.

Вторая сфера - это так называемое непосредственное деловое окружение предприятия. Это окружение формируют такие субъекты среды, которые непосредственно связаны или непосредственно воздействуют на деятельность данной конкретного предприятия. При этом важно подчеркнуть, что и предприятие в свою очередь может непосредственно влиять на них.

Общее внешнее окружение формируется под влиянием политических, правовых, социальнокультурных, экономических, технологических, национальных и международных процессов, а также процессов природопользования.

Непосредственное деловое окружение предприятия создают покупатели, поставщики, конкуренты, деловые партнеры, а также регулирующие службы и такие организации, как административные органы, деловые объединения и ассоциации, профсоюзы и т.п.

Управляя процессами взаимодействия предприятия с окружающей средой, менеджмент сталкивается с рядом серьезных проблем, порождаемых неопределенностью в состоянии окружающей среды. В связи с этим одной из сложнейших задач, стоящих перед менеджментом, является снижение неопределенности положения предприятия в окружении. Это достигается путем развития его адаптивности к внешней среде и установления широких связей с окружением, позволяющих предприятию органично вписываться в окружающую среду.

В зависимости от того, насколько предприятие адаптивно к изменениям в окружении, выделяется два типа управления предприятием:

1) механистический тип управления; 2) органический тип управления.

Механистический тип управления предприятием характеризуется набором следующих характеристик:

$\square$ - консервативная, негибкая структура;

$\square$ - четко определенные, стандартизированные и устойчивые задачи;

$\square$ - сопротивление изменениям;

$\square$ - власть проистекает из иерархических уровней в организации и из позиции в организации;

$\square$ - иерархическая система контроля;

- командный тип коммуникаций, идущих сверху вниз;

$\square$ - содержанием коммуникаций преимущественно являются распоряжения, инструкции и принятые руководством решения.

Органического типа управлению предприятием характерно:

$\square$ - гибкая структура; 
задачи;

- динамичные, не жестко определенные

$\square$ - готовность к изменениям;

- власть базируется на знании и опыте;

- самоконтроль и контроль коллег;

$\square$ - многонаправленность коммуникаций (вертикальные, горизонтальные, диагональные и др.);

$\square$ - содержанием коммуникаций являются информация и советы.

Каждый из данных типов имеет определенные преимущества.

Соответственно каждому из данных типов может быть дано определенное предпочтение в зависимости от характера окружения и уровня неопределенности. В том случае, если окружение динамично, если высок уровень неопределенности, более эффективным является органический тип управления предприятием. Если же окружение стабильно и неопределенность находится на низком уровне, предпочтение может быть отдано механисгическому типу управления.

Развитие взглядов на управление: «одномерные» и «синтетические» учения:

Приступая к анализу развития учения об управлении, следует помнить о том, что основная задача управления - координация усилий всех элементов предприятия в деле осуществления успешности его функиионирования.

Полезно обратить внимание на строение внутренней среды организации, выделяя такие элементы как цели, кадры, задачи, технологию и структуру.

Надо помнить и о наличии внешней среды предприятия, четко понимая, что именно оно открывает доступ к ресурсам и, тем самым определяет возможность его существования.

Совершенно недопустимо забывать при этом о том, что «человек думает, потому, что он делает». И, хотя сама мысль не подвластна времени, ее материализация, осуществляется во времени и пространстве $u$, самое главное, требует затрат энергии.

Другими словами, развитие мысли реально возможно только при наличии опыта ее реализации.

Практика управления также стара, как и предприятие . На глиняных табличках, датированных третьим тысячелетием до нашей эры, записаны сведения о коммерческих сделках и законах древней Шумерии.

Будем иметь в виду: Задача - это иель в конкретных условия. Задача (задание) - это предписанная работа, серия работ или часть работы, которая должна быть выполнена заранее установленным способом в заранее оговоренные сроки. Задачи предписываются должности, а не работнику.

Взгляды на управление развивались по мере того, как развивались общественные отношения, совершенствовалась технология производства, появлялись новые средства связи и обработки информации. Однако управленческая мысль всегда знаменовала собой рубежи, начиная с которых происходили широкие преобразования в практику управления.

Управленческая мысль постоянно обращается к сфере самой коллективной деятельности или деятельности управления. Если в первой выделить субъектный и объектный планы, то получим три области внимания и поисков: задачи, люди и управленческая деятельность. Для начальной стадии развития науки об управлении было характерно акцентирование внимания на одной из них (одномерные учения), в последующем охват количества изучаемых факторов увеличивался (многомерные, синтетические учения).

К настоящему времени эти две группы важнейших подходов, достаточно развиты и представляют совместно системно определившуюся науку об управлении.

«Одномерные» учения об управлении

К числу наиболее заметных учений этой группы можно отнести: научное управление, бихевиористские учения и организачионные теории.

Основателем и основным разработчиком идей научного управления является Фредерик Тейлор (1856 - 1915). Начав с рабочего, он прошел по всем уровням иерархии до главного инженера в сталелитейной компании. Тейлор был инженером, поэтому для него было совершенно естественным (в пределах парадигмы своего времени) смотреть на управление человеком как на управление машиной. Базируясь на механистическом понимании сущности деятельности человека труда, его места в организации, Тейлор видел решение проблемы успешности предприятия в рационализации трудовых операций. Потому для него исходным было изучение задачи. При этом он полагал, что рабочие по своей натуре - ленивые и хорошо работать могут, в лучшем случае, при экономическом стимулировании. А потому управленцы должны думать, а рабочие работать.

Основные принцииь научного управления Тейлора состоят в следующем:

$\square$ разработка оптимальных приемов и методик осуществления работы на базе научного изучения затрат времени на отдельные операции;

$\square$ абсолютное следование научно обоснованным стандартам и нормам;

$\square$ подбор, обучение и расстановка рабочих на те рабочие места и задания, где они, реализуя 
свои способности, могут дать наибольшую отдачу;

$\square$ оплата по результатам труда (чем больше конкретный результат, тем больше оплата);

$\square$ использование функциональных

администраторов, осуществляющих нормоконтроль по специализированным направлениям;

$\square$ поддерживание дружеских отношений между рабочими и менеджерами, с целью реализации научного управления.

Не ослабевая внимания к научной организации труда, в 20 - 30 годы прошлого столетия обратили внимание на то, что производительность труда существенно зависит от социальных условий в организации, и может быть значительно увеличена, если в рабочих группах в процессе совместной деятельности создаются особые отношения - с признаками коллективизма. Перенос центра тяжести в управлении с задач на человека породил развитие различных бихевиористских теорий менеджмента.

Так, Вальтер Дилл Скотт выступал за то, что менеджеры должны смотреть не только сквозь призму их экономических интересов, но и - социальных, признавая их заслуги. Мари Паркер Фоллет считала, что менеджер должен отказаться от формальных взаимодействий с рабочими, быть лидером, признанным рабочими, а не опирающимся на должностную власть. Ее трактовка менеджмента как «искусства добиваться результатов посредством действий других» во главу угла ставила гибкость и гармонию во взаимоотношениях между менеджерами и рабочими, исходя из ситуации, а не уповать на функциональные предписания.

Огромный вклад в развитие бихевиористского направления в управлении внес Абрахам Маслоу. Согласно учению Маслоу человек имеет сложную структуру иерархически расположенных потребностей, и управление в соответствии с этим должно вестись на основе выявления потребностей рабочего и использования соответствующих методов мотивирования.

Конкретное противопоставление научного направления и бихевиористских концепций в виде их теоретического обобщения нашло отражение в теориях «X» и «Y» Дугласа МакГригора . Существуют два типа управления, отражающих в своей основе два диаметрально противоположных взгляда на работников.

Для предприятий типа «Х» характернь следуюшие кониептуальные предпосылки:

$\square \quad$ обычный человек имеет

унаследованную нелюбовь к работе и старается работы;

$\square \quad$ по причине нежелания работать человека только путем принуждения, с помощью приказов, контроля и угроз наказания можно побудить к тому, чтобы он осуществлял необходимые действия и затрачивал должные усилия, для достижения предприятием своих целей;

средний человек предпочитает, чтобы им управляли, старается не брать на себя ответственности, имеет относительно низкие амбиции и желает находиться в безопасной ситуации.

Для предприятий типа «Y» характерны следуюшие предпосылки:

$\square$ выражение физических и эмоциональных усилий на работе для человека также естественно, как и во время игры или отдыха. Внешний контроль и угроза наказания не являются единственными средствами побуждения человека к деятельности. Человек в своей деятельности руководствуется определенным набором ценностей, усвоенными в процессе воспитания, осуществляя самоконтроль и самопобуждение;

$\square$ ответственность и обязательства по отношению к целям организации зависят от вознаграждения, получаемого за результаты труда. Наиболее важным вознаграждением является то, которое связано с удовлетворением потребностей в самовыражении и самоактуализации;

$\square$ обычный человек, воспитанный определенным образом, не только готов брать на себя ответственность, но и даже стремится к этому.

При этом МакГригор подчеркивал, что многим людям присуща готовность использовать свой опыт, знания и воображение в решении проблем предприятия. Однако современное индустриальное общество слабо использует интеллектуальный потенциал обычного человека.

Если, заботясь об успешности деятельности предприятия, Тейлор концентрировал внимание на том, как лучше выполнять задачи, исследуя операции и функции, Мэйо и бихевиористы искали ответы на те же вопросы, обращаясь к природе отношений в коллективе, к мотивам человеческой деятельности, то Фаоль пытался подойти к решению проблемы $c$ позиции совершенствования самой управленческой деятельности.

Анри Файоль (1841 - 1925) почти всю свою сознательную жизнь (58 лет) проработал во французской компании по переработке угля и железной руды. Он считал, опираясь на личный опыт, что при правильной организации своей работы каждый менеджер может добиться успеха.

Рассматривая предприятие как единый организм, Файоль полагал, что для любой 
деловой организации характерно наличие шести определенных видов деятельности, или функиий:

$\square$ техническая деятельность

(производство);

$\square$ коммерческая деятельность (закупка. Сбыт и обмен);

$\square$ финансовая деятельность (поиск и оптимальне использование капитала);

$\square$ деятельность безопасности (защита корпоративной собственности);

$\square$ эккаунтинг (деятельность по анализу, учету, статистике);

$\square$ управление (планирование, функция организации, распорядительство, координация и контроль).

Выделив управление в самостоятельный вид деятельности и наделив его пятью специфическими функциями (планирование, организация, распорядительство, координация и контроль), Файоль разработал четьрнадцать принцииов управления, которым он сам следовал в своей практике и от которых, как он считал, зависит успех управления:

$\square$ Разделение труда (повышает квалификацию и уровень выполнения работы).

$\square \quad$ Власть (право отдавать команды и нести ответственность за результаты).

$\square$ Дисииллина (четкое и ясное взаимопонимание между рабочими и менеджерами, базирующееся на уважении к правилам и договоренностям, существующим на предприятии в основном - результат возможностей руководства).

$\square$ Единство распорядительства (распоряжения только от одного руководителя и подотчетность только одному руководителю).

Единство руководства (один руководитель и единый план для каждого набора действий по достижению каких-то единых целей).

Подчинение индивидуальных интересов обиим интересам (менеджер должен добиваться с помощью личного примера и жесткого, но справедливого управления того, чтобы интересы индивидов, групп и подразделений не превалировали над интересами предприятия в целом).

$\square$ Вознаграждение персонала (оплата должна отражать состояние предприятия и стимулировать людей на работу с отдачей).

$\square$ Централизация (уровень централизации и децентрализации должен зависеть от ситуации и выбираться таким образом, чтобы давать лучшие результаты).

$\square$ Цепи взаимодействия ( четкое построение цепей следования команд от руководства к подчиненным)

Порядок (все должны знать свое место на предприятии).
Равенство (к рабочим следует подходить справедливо и по-доброму).

$\square$ Стабильность персонала (кадры должны находиться в стабильной ситуации).

$\square$ Иницииатива (менеджеры должны поощрять подчиненных выдвигать идеи).

$\square$ Корпоративный дух ( следует создавать дух единства и совместных действий, развивать бригадную форму работы).

Утверждая

универсальность сформулированных принципов, Файоль тем не менее подчеркивал необходимость их гибкого применения, с учетом ситуации, в которой осуществляется управление.

Несомненно, огромный вклад в развитие управленческой мысли внес немецкий юрист и социолог Макс Вебер (1864 - 1920), разработавший теорию бюрократического построения предприятия и системы управления в частности.

Вебер считал, что бюрократическая система должна обеспечить работу предприятия как машины, гарантируя скорость, точность, порядок, определенность, непрерывность

и предсказуемость

Основными принципами построения предприятия, обеспечивающими эти качества, по Веберу, должны быть следующие:

$\square$ разделение труда на базе функциональной специализации;

$\square$ хорошо определенная иерархическая система распределения власти;

$\square$ система правил и норм, определяющих права и обязанности работников;

$\square$ система правил и процедур поведения в конкретных ситуациях;

$\square$ отсутствие личностного начала в межличностных отношениях;

$\square \quad$ прием на предприятие на основе компетентности и потребностей предприятия;

$\square$ продвижение по службе на основе компетентности и широких знаний предприятий, которые приходят с выслугой лет;

$\square$ стратегия к пожизненному найму;

$\square$ четкая система карьеры, обеспечивающая продвижение наверх для квалифицированных работников;

$\checkmark$ управление административной деятельностью состоит в разработке и установлении доскональных письменных инструкций на предприятиях.

\section{«Синтетические» учения об управлении}

Для «синтетических» учений характерен взгляд на управление как на многоплановое, комплексное и изменяющееся явление, связанное множеством связей с внутренней и внешней средой предприятия. Первые успехи такого осмысления управления оформились как 
системный подход к предприятию. Открылась возможность глубокого проникновения в систему внутренних и внешних связей и многофакторного анализа, как объекта, так и субъекта управленческой деятельности.

Несомненно, одним из самых выдающихся теоретиков современности в области системного взгляда на управление следует считать Питера Дракера. Центром идей Дракера об управлении является систематизированное учение о менеджменте как о профессиональной деятельности и о менеджере как о профессии. Это позволило организовать изучение менеджмента в учебных заведениях и открыть подготовку менеджеров.

Одним из самых известных теоретических положений, выдвинутых Дракером, является его концепция управления по целям. Идея Дракера о том, что управление должно начинаться с выработки целей и потом переходить к формированию функций, системы взаимодействия и процесса, в корне перевернула логику управления.

Среди «синтетических» учений об управлении заметное место занимают cuтуационные теории. Ситуационные теории дают рекомендации относительно того, как следует управлять в конкретных ситуациях. При этом рекомендуется пошаговый алгоритм решения проблем. Во-первых, необходимо внимательно осуществить анализ конкретной ситуации, выделив какие требования к предприятию предъявляет ситуация и что характерно для ситуации. Bo-вторых, должен быть выбран соответствующий подход к осуществлению управления. B-третьих, управление должно создавать потенциал в предприятии и необходимую гибкость для того, чтобы можно было перейти к новому управленческому стилю, соответствующему ситуации. B-четвертых, управление должно произвести соответствующие изменения, позволяющие подстроиться к ситуации.

Одной из наиболее популярных системных концепций менеджмента является теория «7-S», разработанная в 80-е гг. (США).Было подмечено, что эффективная организация, как правило, формируется на безе семи взаимосвязанных составляющих, изменение каждой из которых с необходимостью требует соответствующего изменения остальных шести. Эти ключевые составляющие являются следующие:

$\square$ стратегия - планы и направления действий, определяющие распределение ресурсов, фиксирующие обстоятельства по осуществлению определенных действий во времени для достижения поставленных целей;

$\square$ структура - внутренняя композиция предприятия, отражающая взаимное положение организационных подразделений, иерархическую субординацию этих подразделений и распределение власти между ними;

$\square$ системы - процедуры и рутинные процессы, протекающие на предприятии;

$\square$ umam - ключевые группы персонала, существующе на предприятии и охарактеризованные по возрасту, полу, образованию и т.п.;

$\square$ стиль - способ, каким руководители управляют предприятием, включая и организационную культуру;

○валификация - отличительные возможности ключевых людей на предприятии;

$\square$ разделенные ценности - смысл и содержание основных направлений деятельности, которые предприятие доводит до своих членов.

В 1981 г. американец Ульям Оучи, на основе японского опыта управления выдвинул теорию «Z», как бы дополняя и развивая идеи МакГригора и нивелируя положения ситуационных теорий. Исходным пунктом концепции Оучи является положение о том, что человек - это основа любой предприятия и от него в первую очередь зависит успех функционирования предприятия. Исходя из этого, Оучи и сформулировал основные положения и правила эффективного управления людьми.

Идеи теории «Z» в сжатом виде сводятся к следующему:

$\square$ долгосрочный наем кадров;

$\square$ групповое принятие решений;

— индивидуальная ответственность;

медленная дифференцированная оценка

кадров и их умеренное пошаговое продвижение по службе;

$\square$ косвенный, неформальный контроль четкими и формализованными методами;

$\square$ неспециализированная карьера;

$\square$ всесторонняя забота о работниках.

Этот обзор учений об управлении показывает, что практика постоянно высвечивает все новые и новые проблемные грани управления совместной деятельностью, возникающие при поступательном ее развитии. Наука, в свою очередь, своевременно и эффективно отвечает на запросы практики, выдвигая при этом своего рода ориентиры, весьма полезные для практиков, так направляемые четырехступенчатую модель достижения успеха, а именно:

1. Решите, чего вы хотите (сформулируйте и поставьте перед собою цель).

2. Сделайте что-нибудь.

3. Посмотрите, что получится.

4. Если понадобится - меняйте подход, пока не добьетесь желаемого.

Ставить верные цели - это значит - уметь «правильно сформулировать результат». 
Основные принцииь формирования и выбора своих изелей:

1. Выбирайте такие цели, которые заслуживают их достижения.

2. Выбирайте такую цель, которой сможете достичь своими силами.

3. Формулируйте свою цель в утвердительных терминах.

4. Выражайте свою цель точно, в сенсорных категориях.

5. Соотносите свою цель с контекстом (ситуацией).

6. Трезво оценивайте последствия достижения своей цели.

Подсознание играет важную роль во всем, что мы делаем. Деловые и организационные методы достижения целей (формализованные) обычно опускают этот фактор. То же относится и к индивидуальным целям, выбранным логическим, систематическим путем, «левым полушарием».

Думать в утвердительной форме - это принцип правильной формулировки результата.

С сожалением, обычно сосредотачиваются на попытках избежать нежелательного вместо того, чтобы думать о желаемом и добиваться желаемого. У них формируется «агрессивнооборонительный», «отрицающий» характер вместо «утверждающего». «Отрицающий человек» переживает, в конце концов, тот сценарий, которого хотел бы избежать, ибо именно он закрепляется стратегически и реализуется. Можно назвать такую систему «избегания» осмотрительностью, реализмом, благоразумием и так далее. Наиболее действенно она проявляется при достижении внутренних целей, но когда дело касается осознаваемых целей «...?.», она нередко приводит к непостижимым на первый взгляд промахам. Потому первый принцип правильно сформулированного результата гласит: «Выражаю свою цель в утвердительных терминах».

Принципы

сбалансированного самообновления

Возможно, мы начали понимать, что если мы хотим что-либо изменить, то начинать изменение надо с себя. И для того, чтобы изменить себя эффективно, мы, прежде всего, должны поменять свое восприятие.

Принципы НЛП (нейро-лингвистического программирования) предполагают учет всех четырех измерений. Это означает, что мы должны регулярно и последовательно развивать их самым разумным и сбалансированным образом. Расходование времени на самообновление требует от нас инициативы.

Эффективные навыки - хорошо усвоенные принципь и модели поведения. Чтобы что-то в своей жизни превратить в навык, необходимы три компонента: Знание, Умение, Желание .

Знание - это теоретическая парадигма, определяющая что делать и зачем. Умение определяет

как делать. А желание - это мотивация хочу делать.

Если однажды мы поверим, что отныне наше поведение зависит от наших решений, а не от окружающих условий, то самый первый навык, необходимый при начавшемся саморазвитии личности - это проактивность. Под проактивностью надо понимать, осмыслив ее как факт, что, инициируя происходящее, подчиняя чувства нашим ценностям, мы несем ответственность за свои действия (и, прежде всего, перед собой). Поведение проактивного человека есть продукт его собственного выбора, он не ищет «виноватых» за свои поступки и за их результаты. В этом случае он себя спрашивает, и в себе ищет ответ. Стивен Р. Кови полагает, что для достижения личной nобеды (победы над собой) человеку как минимум нужно еще два навыка (рисунок 1) (кроме - «Будь проактивным» (1): это - «Начинай, представляя конечную цель» (2), и «Сначала делай то, что необходимо делать сначала» (3).Если в значении цели в нашей деятельности мы уже достаточно четко определились, то с третьим навыком надо еще разобраться. В данном случае имеется в виду необходимость управлять своим временем, четко представляя степень важности и срочности тех дел, которые намечаем к исполнению. 


\begin{tabular}{|c|c|c|c|c|c|c|}
\hline Impact Factor: & $\begin{array}{l}\text { ISRA (India) } \\
\text { ISI (Dubai, UAE } \\
\text { GIF (Australia) } \\
\text { JIF }\end{array}$ & $\begin{array}{r}=1.344 \\
=0.829 \\
=0.564 \\
=1.500\end{array}$ & $\begin{array}{l}\text { SIS (USA) } \\
\text { PИНЦ (Russia) } \\
\text { ESJI (KZ) } \\
\text { SJIF (Morocco) }\end{array}$ & $\begin{array}{l}=0.912 \\
=0.207 \\
=4.102 \\
=2.031\end{array}$ & $\begin{array}{l}\text { ICV (Poland) } \\
\text { PIF (India) } \\
\text { IBI (India) }\end{array}$ & $\begin{array}{l}=6.630 \\
=1.940 \\
=4.260\end{array}$ \\
\hline
\end{tabular}

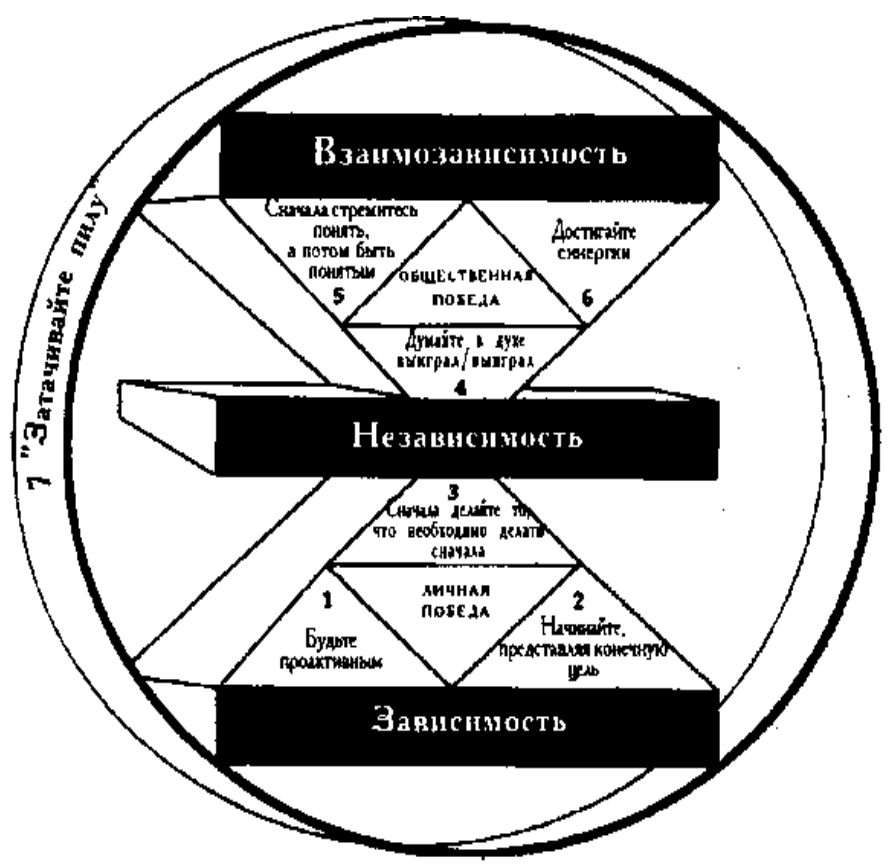

Рисунок 1 - Матрица управления временем:

1 - Будь проактивным, 2 - Начинай, представляя конечную цель 3 - Сначала делай то, что необходимо делать сначала 4 - Думайте в духе выйграл/выйграл 5 - Сначала стремитесь понять, а потом быть понятым

6 - Достигайте синергии, 7 - «Затачивайте пилу»

Вполне очевидно, что для овладения навыком «Сначала делай то, что необходимо делать сначала», не срочные, но весьма важные дела по поддержанию своего ресурса будем стараться делать в первую очередь, и именно в этом деле как раз и будем нарабатывать первый и второй навык.

По мере овладения первыми тремя навыками мы все больше приобретем независимость от внешних факторов и все больше открываем возможность закрепить личную победу, пробуя по-новому взаимодействовать с окружающим нас миром себе подобных, осознавая объективную взаимозависимость. Для этого нам понадобятся еще три навыка: «Думай в духе выиграл/выиграл» (4), «Сначала стремись понять, a потом быть понятым»(5),»Достигайте синергии»(6). Сотрудничество и доверие - и результат и условие для закрепления этих важных в общении и коллективной деятельности навыков.

Седьмой навык (7) Стивен Р. Кови назвал «Затачивай пилу».

Он не двусмысленно полагал (рисунок 5), что мы можем рассчитывать на успех, на эффективность только тогда, когда будем делать постоянные усилия в деле формирования всех названных навыков, работая над всесторонним саморазвитием.
Таким образом, надо признать, что, работая над своим обновлением в одиночку, сомнительно добиться успеха, даже имея все три составляющие для формирования необходимых навыков. Человек - существо социальное. Реально воспитание осуществляется только через поступок. В воспитании участвуют трое: кроме воспитуемого, еще должны быть воспитатель (делай как я) и ценитель (того чему учат и как получается). При самовоспитании - где взять еще двух недостающих? Выход только один - найти образ, который бы был учителем, найти образ, который был бы ценителем. Мы не оговорились, а вы не ошиблись - именно образ или образы. Для этого могут подойти литературные герои, друзья, подруги, папы, мамы, бабушки, дедушки ... при вашем богатом воображении.

Вновь хочется вспомнить ещё одну русскую пословицу: «Что пока гром не грянет, мужик не перекрестится». Неужели обязательно наступить на грабли, получить ощутимый удар по лбу и закричать - «Фу, вспомнил название этого инструмента, что это грабли ». Смешно и грустно, и все же верим в здравый смысл, что истина дороже и правда восторжествует - мы сможем реанимировать эту самую легкую промышленность, что и подтвердили эксперты респонденты, проявив единодушие, по основным критериям оценки конкурентоспособности предприятий легкой промышленности, перечень 
которых, утвержденный по итогам совещания, приведены ниже.

1. Правительству Российской Федерации:

a) предусмотреть при формировании проекта федерального бюджета на 2018 год и на плановый период 2019 и 2020 годов предоставление государственной поддержки предприятиям лёгкой промышленности ежегодно в объёмах не ниже уровня 2017 года.

Доклад - до 15 октября 2017 г. и до 15 января 2018 г.;

б) предусмотреть в рамках Государственной программы развития сельского хозяйства и регулирования рынков сельскохозяйственной продукции, сырья и продовольствия на 2013 2020 годы формирование подпрограммы, направленной на обеспечение лёгкой промышленности качественным сельскохозяйственным сырьём, а также реализацию противоэпизоотических мероприятий в целях ликвидации гиподерматоза крупного рогатого скота.

Срок - 1 февраля 2018 г;

в) рассмотреть вопрос об установлении на федеральном уровне льгот по налогу на имущество организаций в отношении движимого имущества в целях стимулирования модернизации производства и обеспечить внесение соответствующих изменений в законодательство Российской Федерации;

г) принять меры по смягчению в рамках двусторонних международных соглашений с центральными ветеринарными органами зарубежных стран ветеринарных требований, предъявляемых к кожевенному сырью, ввозимому на территорию Российской Федерации;

д) определить реализацию тонкой и полутонкой шерсти, длинного льняного волокна перерабатывающим предприятиям, расположенным на территории Российской Федерации, в качестве обязательного условия предоставления государственной поддержки сельскохозяйственным товаропроизводителям, осуществляющим производство данной продукции, и обеспечить внесение соответствующих изменений в нормативные правовые акты;

е) предусмотреть внесение в законодательство Российской Федерации изменений, направленных на развитие системы обеспечения прослеживаемости оборота товаров легкой промышленности.;

ж) рассмотреть вопрос о целесообразности введения утилизационного сбора в отношении обуви;

3) совместно с акционерным обществом «Российский экспортный центр» представить предложения по содействию развитию экспорта российской продукции легкой промышленности, в том числе путём компенсации затрат, связанных с выходом названной продукции на внешние рынки.

Радует, что предполагается их реализация в полном объёме и установленные сроки, понимая ответственность названных лиц и наличие у них мотивации действий.

Несмотря на принциииальные отличия выме рассмотренных этих концепџий, они, тем не менее, имеют нечто общее в своей основе, что отражает определенную общность в мотивации человека к действиям.

Названные концепции Маслоу, Альдерфера, Мак Клеллакда, Герцберга позволяют сделать вывод о том, что отсутствует какое-либо канонизированное учение, объясняющее то, что лежит в основе мотивации человека и чем определяется мотивация. Каждая из изложенных теорий имеет определенное принципиальное отличие.

Таким образом,, каждая из теорий имеет что-то особенное, отличительное, что дало ей возможность получить широкое признание теоретиков и практиков и внести существенный вклад в разработку знаний о мотивации. Однако при этом, несмотря на принципиальные различия, все четыре вышеописанные теории имеют нечто общее, позволяющее установить определенные параллели между ними. Характерной особенностью всех четырех теорий является то, что они изучают потребности и дают классификацию потребностей, позволяющую делать некие выводы о механизме мотивации человека. Сравнивая классификации всех четырех теорий, можно отметить, что выделенные в различных теориях группы потребностей достаточно определенно соответствуют друг другу.

Многое зависит от организационной культуры и управления коллективом предприятий легкой промышленности.

Предприятие - это сложный организм, основой жизненного потенциала которого является организационная культура: то, ради чего люди стали членами предприятия; то, как строятся отношения между ними; какие устойчивые нормы и принципы жизни и деятельности предприятия они разделяют; что, по их мнению, хорошо, а что плохо, и многое другое из того, что относится к ценностям и нормам. Все это не только отличает одну организацию от другой, но и существенно предопределяет успех функционирования и выживания предприятия в долгосрочной перспективе. Организационная культура не так явно проявляется на поверхности, ее трудно «пощупать». Если можно говорить о том, что предприятие имеет «душу», то этой душой является организационная культура. 
Носителями организационной культуры являются люди. Однако на предприятиях с устоявшейся организационной культурой они как бы отделяются от людей и становятся атрибутом предприятия, его частью, оказывающей активное воздействие на членов предприятия, модифицирующей их поведение в соответствии с теми нормами и ценностями, которые составляют его основу.

Так как культура играет очень важную роль в жизни предприятия, то оно должна являться предметом пристального внимания со стороны руководства. Управление не только соответствует организационной культуре и сильно зависит от нее, но и может в свою очередь оказывать влияние на формирование и развитие организационной культуры. Для этого менеджеры должны уметь анализировать организационную культуру и оказывать влияние на ее формирование и изменение в желательном направлении.

\section{Понятие и структура организационной культурь}

В современной литературе существуют как очень узкие, так и очень широкие толкования того, что же представляет собой культура предприятия.

Чаще всего организационная культура трактуется как принимаемые большей частью предприятия философия и идеология управления, предположения, ценностные ориентации, верования, ожидания, расположения и нормы, лежащие в основе отношений и взаимодействий как внутри предприятия, так и за его пределами.

Используя то общее, что присуще многим определениям, можно понимать организационную культуру следующим образом. Организаиионная культура - это набор наиболее важных предположений, принимаемых коллективом предприятия $u$ получаюших выражение $в$ заявляемых предприятием ценностях, задающих людям ориентиры их поведения $и$ действий. Эти ценностные ориентации передаются индивидам через «символические» средства духовного и материального внутриорганизационного окружения.

Базовые предположения это то, чего придерживается коллектив предприятия в своем поведении и действиях. Эти предположения часто связаны с видением окружающей индивида среды (группы, предприятия общества, мира) и регулирующих ее переменных (природа, пространство, время, работа, отношения и т. д.). Нередко бывает трудно сформулировать это видение применительно к предприятию.
Ценности (или ценностные ориентации) ориентируют индивида в том, какое поведение следует считать допустимым или недопустимым. Так, на некоторых предприятиях считается, что «клиент всегда прав», поэтому в них недопустимо обвинять клиента за неудачу в работе коллектива предприятия . В других - может быть все наоборот. Однако и в том, и в другом случае принятая ценность помогает индивиду понять то, как он должен действовать в конкретной ситуации.

«Символика» это то, посредством чего ценностные ориентации «передаются» коллективу предприятия. Многие предприятия имеют специальные, предназначенные для всех документы, в которых они детально описывают свои ценностные ориентации. Однако содержание и значение последних наиболее полно раскрываются работникам через «ходячие» истории, легенды и мифы. Их рассказывают, пересказывают, толкуют. В результате этого они оказывают иногда больше влияния на индивидов, чем те ценности, которые записаны в рекламном буклете предприятия.

Организационная культура имеет определенную структуру. Последнюю можно рассматривать как трехуровневую.

Первыій, «поверхностныйџ,, или «символический» уровень. Включает такие видимые внешние факты, как - применяемая технология и архитектура, использование пространства и времени, наблюдаемое поведение, язык, лозунги и т.П., или все то, что можно ощущать и воспринимать через известные пять чувств человека (видеть, слышать, ощущать вкус и запах, осязать). На этом уровне вещи и явления легко обнаружить, но не всегда их можно расшифровать и интерпретировать в терминах организационной культуры.

Второй, «подповерхностный» уровень. На этом уровне обнаруживаются ценности и верования, разделяемые коллективом предприятия, в соответствии с тем, насколько эти ценности отражаются в символах и языке. Восприятие ценностей и верований носит сознательный характер и зависит от желания людей.

Третий, «глубинный» уровень. Включает базовые предположения, которые трудно осознать даже самим коллективом предприятия без специального сосредоточения на этом вопросе. Эти скрытые и принимаемые на веру предположения направляют поведение людей, помогая им воспринять атрибуты, характеризующие организационную культуру.

Соответственно тому, какие из указанных уровней изучаются, существует деление организационных культур на субъективные и объективные.

Субъективная организационная культура исходит из разделяемых работниками образцов 
предположений, веры и ожиданий, а также из группового восприятия организационного окружения с его ценностями, нормами и ролями, существующими вне личности. Сюда включают ряд элементов «символики», особенно ее «духовной» части: герои предприятия, мифы, истории о предприятии и его лидерах, организационные табу, обряды и ритуалы, восприятие языка общения и лозунгов. Субъективная организационная культура служит основой формирования управленческой культуры, т.е. стилей руководства и решения руководителями проблем, их поведения в целом. Это создает различие между схожими на вид организационными культурами. Например, два предприятия могут заявлять о качественном обслуживании своих клиентов. Но конечный результат будет во многом зависеть от того, как будет осуществляться руководство этим процессом.

Объективную организационную культуру обычно связывают с физическим окружением, создаваемым на предприятии: само здание и его дизайн, места расположения, оборудование и мебель, цвета и объем пространства, удобства, кафетерий, комнаты приема, стоянки для автомобилей и сами автомобили. Все это в той или иной степени отражает ценности, которых придерживается коллектив предприятия . Хотя оба аспекта организационной культуры важны, однако субъективный аспект создает больше возможностей для нахождения как общего, так и различий между людьми и между предприятиями.

Содержание организационной культуры

Конкретную организационную культуру можно рассматривать на основе десяти характеристик:

$\square$ осознание себя и своего места на предприятии (одни культуры ценят сокрытие работником своих внутренних настроений, другие - поошряют их внешнее проявление; в одних случаях независимость и творчество проявляется через сотрудничество, а в других - через индивидуализм);

$\square$ коммуникационная система и язык общения (использование устной, письменной, невербальной коммуникации, «телефонного права» и открытости коммуникации разнится от группы к группе, от предприятия к предприятию; жаргон, аббревиатуры, жестикуляции варьируются в зависимости от отраслевой, функциональной и территориальной принадлежности предприятий);

$\square$ внешний вид, одежда и представление себя на работе (разнообразие униформ и спецодежды, деловых стилей, опрятность, косметика, прическа и т.п. подтверждают наличие множества микрокультур);

$\square$ что и как едят люди, привычки и традиции в этой области (организация питания работников, включая наличие или отсутствие таковых мест на предприятии; люди приносят с собой еду или посещают кафетерий внутри или вне предприятия; дотация питания; периодичность и продолжительность питания; едят ли работники разных уровней вместе или отдельно и т.п.);

$\square$ осознание времени, отношение к нему и его использование (степень точности и относительности времени у работников; соблюдение временного распорядка и поощрение за это; моно хроническое или полихроническое использование времени);

$\square$ взаимоотношения между людьми (по возрасту и полу, статусу и власти, мудрости и интеллекту, опыту и знаниям, рангу и протоколу, религии и гражданству и т.п.; степень формализации отношений, получаемой поддержки, пути разрешения конфликтов);

$\square$ ценности (как набор ориентиров в том, что такое хорошо и что такое плохо) и нормы (как набор предположений и ожиданий в отношении определенного типа поведения) - что люди ценят в своей организационной жизни (свое положение, титулы или саму работу и т.п.) и как эти ценности сохраняются;

$\square$ вера во что-то и отношение или расположение к чему-то (вера в руководство, успех, в свои силы, во взаимопомощь, в этичное поведение, в справедливость и т.п.; отношение к коллегам, клиентам и конкурентам, к злу и насилию, агрессии и т.п.; влияние религии и морали);

$\square$ процесс развития работника и научение (бездумное или осознанное выполнение работы; полагаются на интеллект или силу; процедуры информирования работников; признание или отказ от примата логики в рассуждениях и действиях; абстракция и концептуализация в мышлении или заучивание; подходы к объяснению причин);

$\square$ трудовая этика и мотивирование (отношение к работе и ответственность по работе; разделение и замещение работы; чистота рабочего места; качество работы; привычки по работе; оценка работы и вознаграждение; отношения «человек - машина»; индивидуальная или групповая работа; продвижение по работе).

Выше отмеченные характеристики культуры предприятия, взятые вместе, отражают и придают смысл концепции организационной культуры.

Члены предприятия , разделяя веру и ожидания, создают свое физическое окружение, вырабатывают язык общения, совершают адекватно воспринимаемые другими действия и проявляют понимаемые всеми чувства и эмоции. Bce это, будучи воспринятым работниками, помогает им понять и интерпретировать культуру предприятия, т.е. придать свое значение 
событиям и действиям и сделать осмысленным свое рабочее окружение. Поведение людей и групп внутри коллектива предприятия сильно связано нормами, вытекающими из этих разделяемых верований, ожиданий и действий.

Содержание организационной культуры влияет на направленность поведения и определяется не простой суммой предположений, а тем, как они связаны между собой и как они формируют определенные образцы поведения. Отличительной чертой той или иной культуры является относительный порядок, в котором располагаются формирующие ее базовые предположения, что указывает на то, какая политика и какие принципы должны превалировать в случае возникновения конфликта между разными наборами предположений планированию карьеры.

Влияние культуры на организационную эффективность.

Различается два пути влияния культуры на организационную жизнь. Первый, - культура и поведение взаимно влияют друг на друга. Второй культура влияет не столько на то, что люди делают, сколько на то, как они это делают. Существуют различные подходы к выделению набора переменных, посредством которых прослеживается влияние культуры на предприятие.

Модель Сате. Влияние культуры на организационную жизнь В. Сате рассматривает через семь прочессов:

$\square$ кооперация между индивидами и частями предприятия;

$\square$ контроль; коммуникации; посвященность предприятия; восприятие организационной среды; оправдание своего поведения.

При этом первые три процесса корреспондируются с первым, поверхностным уровнем организационной культуры или образцами организационного поведения, а следующие четыре - со вторым, подповерхностным уровнем, имеющим «ценностную» основу. От того, как эти процессы протекают, зависит эффективность функционирования предприятия.

Кооперациию как образец поведений на предприятии нельзя установить только с помощью формальных управленческих мер, так как нельзя предусмотреть все возможные случаи. Насколько действительно люди кооперируются в коллективы предприятий , зависит от разделяемых ими предположений в этой области, В одних предприятиях высшей ценностью является групповая работа, в Других - внутренняя конкуренция. Говоря другими словами, все зависит от того, какая философия преобладает: индивидуалистская или коллективистская.
Влияние культуры на принятие решений осуществляется через разделяемые верования и ценности, формирующие у членов организации устойчивый набор базовых предположений и предпочтений. Так как организационная культура может способствовать сведению к минимуму разногласий, то процесс принятия решений становится более эффективным.

Сущчность процесса контроля заключается в стимулировании действий в направлении достижения поставленных целей. В природе управления существуют три механизма контроля: рынок, администрирование, клановость. Обычно в коллективах предприятий присутствуют все три механизма сразу, но в разной степени. При рыночном механизме контроля полагаются в основном на цены. Лежащее в основе этого предположение заключается в том, что меняющиеся цены и платежи должны стимулировать необходимые изменения на предприятии.

Административный механизм контроля строится на формальном авторитете. Сам процесс состоит в изменении правил и процедур посредством издания директив. В основе данного механизма лежат два предположения:

$\square$ сверху виднее, какими мерами достичь желаемого результата;

$\square$ работники подчиняются без вопросов в пределах разделяемых базовых предположений.

Клановый механизм контроля всецело основан на разделяемых верованиях и ценностях. Именно из них исходят члены коллектива предприятия при осуществлении своих действий. Предполагается также, что работники достаточно привержены предприятию, знают, как действовать в рамках данной культуры. По мере роста и развития предприятия клановый механизм заменяется административным, а затем и рыночным.

Влияние культуры на коммуникации происходит по двум направлениям. Первое - это отсутствие необходимости коммуницировать в делах, по которым имеются разделяемые предположения. В этом случае определенные действия совершаются как бы без слов. Второе разделяемые предположения обеспечивают направленность и оказывают помощь в интерпретации получаемых сообщений. Так, если на предприятии работник не считается придатком машины, то и известие о предстоящей автоматизации или роботизации не вызовет в нем шока.

Содержание культуры влияет также на содержание коммуникации. В одних предприятих ценится открытость коммуникаций, а в других наоборот.

Индивид чувствует себя посвященным предприятию тогда, когда он отождествляет себя с последний и испытывает некоторую 
эмоциональную связь с ним. Сильная культура делает сильным отождествление и чувства индивида по отношению к предприятию. Также работники могут активизировать свои действия в стремлении помочь предприятию.

Восприятие индивидом организационной реальности или то, что он видит, обусловлено в значительной мере тем, что говорят об увиденном его коллеги, разделяющие с ним один и тот же опыт. Культура влияет на этот процесс, обеспечивая членов коллектива предприятия общей интерпретацией их опыта. На предприятиях, где высоко ценится своевременное обслуживание потребителя, восприятие недостатка в ресурсах для работы не будет интерпретировано как необходимость изменения выработанного расположения к клиенту. В противоположном случае клиент может серьезно пострадать.

Культура помогает людям на предприятии действовать осмысленно, обеспечивая оправдание ux поведению.На предприятиях, где ценится риск, человек идет на него, зная, что в случае неудачи он не будет наказан и что из неудачи будут извлечены уроки на будущее. Оправдываемые таким образом действия усиливают существующее поведение, особенно когда оно вписывается в ситуацию. Данный процесс является источником средств для изменения самой культуры. Поскольку люди используют культуру для оправдания поведения, то можно изменять культуру через изменение в поведении. Однако для успеха этого процесса необходимо обеспечить, чтобы люди не могли бы оправдывать свое новое поведение «старой» культурой.

Модель Питерса - Уотермана. Авторы известного бестселлера «В поисках успешного управления» Т. Питерс и Р. Уотерман обнаружили связь между культурой и успехом в работе предприятия. Взяв за образец успешные американские фирмы и описав управленческую практику, они «вывели» ряд верований и ценностей организационной культуры, приведших эти предприятия к успеху:

$\square$ вера в действия;

$\square$ связь с потребителем;

$\square$ поощрение автономии и

предприимчивости;

$\square$ рассмотрение людей как главного

источника производительности и эффективности;

$\square$ знание того, чем управляешь;

не заниматься тем, чего не знаешь;

простая структура и немногочисленный

штат управления;

$\square$ одновременное сочетание гибкости и жесткости на предприятии .

Вера в действия. Согласно этой ценности, решения принимаются даже в условиях недостатка информации. Откладывание решений равносильно их непринятию.

Связь с потребителем. Для успешно действующих предприятий потребитель представляет фокус в их работе, так как именно от него поступает главная информация для предприятия. Удовлетворенность потребителя для таких предприятий составляет сердцевину их организационной культуры.

Автономия $u$ предприимчивость. Предприятия, борющиеся с недостатком нововведений и бюрократией, «делятся» на более мелкие управляемые части и предоставляют им, а также отдельным индивидам определенную степень самостоятельности, необходимой для проявления творчества и риска. Эта культурная норма поддерживается через распространение на предприятии легенд и историй о своих собственных «эдисонах» и «фордах».

Производительность зависит от человека. Данная ценность провозглашает человека наиболее важным активом предприятий. При этом, эффективность предприятия измеряется через удовлетворенность его членов. Вера в то, что отношение к людям с уважением и достоинством ведет к успеху, лежит в основе культуры подобных предприятий.

Знай то, чем управляешь. В соответствии с этой глубоко укоренившейся культурной нормой успешных предприятий ожидается, "что они управляются не из-за закрытых дверей кабинетов руководителей, а через посещение руководителями управляемых ими объектов и через непосредственные контакты с подчиненными на местах их работы.

Не занимайся тем, чего не знаешь. Данное положение относится к разряду одной из важных характеристик культуры успешно действующих предприятий. Эти предприятия не приемлют диверсификации в сторону от основного бизнеса.

Простые структуры и мало управленцев. Типичным для успешно действующих предприятий является наличие небольшого числа уровней управления и сравнительно небольшого штата управленческих работников, особенно в высшем эшелоне. Положение менеджера на таких предприятия определяется не количеством его подчиненных, а его влиянием на дела предприятия и, главное, на его результаты. Согласно этой культурной ценности, менеджеры больше ориентируются на уровень выполнения подчиненными своей работы, а не на наращивание своих штатов.

Одновременная гибкость и жесткость на предприятии . Парадокс этого атрибута организационной культуры успешных предприятий разрешается следующим образом. Высокая 
организованность в них достигается за счет того, что все работники понимают и верят в ценности предприятия. Это их жестко связывает и интегрирует. Гибкость обеспечивается посредством сведения к минимуму «руководящих» вмешательств и минимизации числа регулирующих правил и процедур. Это поощряет новаторство и стремление брать на себя риск. В итоге жесткая структура разделяемых культурных ценностей делает возможной гибкую структуру административного контроля.

Модель Парсонса. В более общем виде связь между культурой и результатами деятельности предприятия представлена в модели американского социолога Т. Парсонса. Модель разработана на основе спецификации определенных функций, которые любая социальная система, в том числе предприятие, должно выполнять, чтобы выжить и добиться успеха. Первые буквы английских названий этих функций в аббревиатуре дали название модели - AGIL:

$\square$ адаптация;

достижение целей;

интеграция;

легитимность

Суть модели состоит в том, что для своего выживания и процветания любое предприятие должно быть способным адаптироваться $\kappa$ постоянно меняющимся условиям внешней среды, добиваться выполнения поставленных им цеелей, интегрировать свои части в единое целое и, наконец, быть признанным людьми и другими предприятиями.

Данная модель исходит из того, что ценности организационной культуры являются наиболее важными средствами или инструментами выполнения функций этой модели. Если разделяемые в коллективе предприятия верования и ценности помогают ему адаптироваться, достичь целей, объединиться и, доказать свою полезность людям и другим предприятиям, то очевидно, такая культура будет влиять на предприятие в направлении успеха.

Модель Квина - Рорбаха. Идеи Т. Парсонса были развиты и конкретизированы Р. Квином и Дж. Рорбахом в их модели «Конкурирующие ценности и организационная эффективность», объясняющей влияние тех или иных групп ценностей на организационную эффективность. В развитие модели AGIL было предложено рассматривать это влияние не в одном, а в трех измерениях. Поэтому использовалась модель так называемых «конкурирующих ценностей».

Данная модель включает следующие три измерения:

интеграциия - дифференцииачия: относится к проектированию работ и предприятия в целом. Данное измерение указывает на степень, с которой в коллективе предприятия делается упор либо в сторону

контроля (предпочитаются стабильность, порядок и предсказуемость), либо в сторону гибкости (предпочитаются нововведения, адаптация и изменения);

внутренний фокус - внешний фокус, данное измерение отражает преобладание в коллективе предприятия интереса либо к устройству его внутренних дел (скоординрованность и удовлетворенность работников), либо к укреплению положения предприятия как целого во внешней среде;

средства/инструментьл

результаты/показатели: измерение в модели демонстрирует различие в концентрации внимания, с одной стороны, на процессы и процедуры (планирование, установление целей и др.), а с другой - на окончательные результаты и показатели их измерений (производительность, эффективность и др.). Эти три измерения «рождают» четыре различных подхода к моделям организационной эффективности: квадрант 1 подход «человеческих отношений», отражающий состояние поддержания системы социальных отношений, обязательств людей, децентрализации и дифференциации через развитие сплоченности и квалификационных навыков у работников; квадрант 2 - подход «открытой системы», отражающий состояние децентрализации и дифференциации, роста и адаптации, улучшения конкурентной позиции для всего предприятия через концентрацию на развитии гибкости и способности к приобретению необходимых ресурсов;

квадрант 3 - подход «рационально-целевой», отражающий усиление конкурентной позиции предприятия в целом, максимизацию результатов, централизацию и интеграцию через акцентирование внимания на планировании, эффективности и производительности; квадрант 4 - подход «внутренних процессов», отражающий состояние централизации и интеграции, консолидации и приемственности, поддержания системы социальных отношений через распределение информации и укрепление стабильности и порядка.

Данная общая модель описывает ценности культуры предприятия в связи с каждым отдельным подходом к определению эффективности и сопоставляет перспективу одного подхода со всеми другими. Измерение конкурирующих ценностей в модели Квина Рорбаха производится с помощью «шкалированных» вопросников. Поэтому, модель может использоваться как эффективный инструмент организационной диагностики. В отличие от одномерных моделей, в данном случае нельзя получить «единственно верный ответ» об 
эффективности предприятия. Модель выявляет недостатки во всех четырех своих частях в той степени, в которой они присутствуют в деятельности предприятия.

Для практики управления важно получить от теории ответ на два вопроса: что надо знать о национальной культуре, чтобы учесть ее влияние на эффективность управления коллективом, и можно ли «сращивать» элементы разных начиональных культур в рамках одного предприятия?

Системный подход. В формировании организационной культуры принимает участие весь «колорит» национальной культуры того общества, в котором данное предприятие функционирует.

Систематизация, как упорядоченность во взаимосвязях между частями, способствует направленности анализа и учета уровня влияния отдельных элементов целого. А они выделяются следующие: система семьи, система образования, экономическая система, системы - политическая, религиозная, сочииализации, здоровья, отдыха.

Система семьи - это семейные отношения и путь, с помощью которого люди воспроизводят, обучают и вводят в общество своих детей. В семье дети впервые вырабатывают образцы поведения, необходимые им для выполнения в будущем различных ролей в коллективе предприятия (например, отношения по статусу, возрасту, полу и т. д.)

Система образования - это то, как молодые и новые члены общества обеспечиваются информацией, знаниями, навыками и ценностными ориентирами. Так, например, в одних культурах больше учат через то, что не надо делать, а в других — наоборот.

Экономическая система - это способ, с помощью которого общество производит и распределяет товары и услуги. При этом имеют место групповой, коллективный и индивидуальный подходы.

Политическая система - это то, что преимущественно используется для поддержания порядка и существующей власти. Это могут быть атрибуты племенного и даже родового подхода, а могут быть элементы развитой демократии.

Религиозная система - это вне материальные, духовные средства обеспечения смысла и мотивации в действиях людей. Эта система определяет мораль и преобладающие ценности в обществе, на которые ориентируются функционирующие в этом обществе предприятия.

Система социализации - это сеть и принципы социального группирования, создаваемые людьми в данном обществе.
Система здоровья - это способ, с помощью которого культура предотвращает и исцеляет заболевания, а также проявляется забота о жертвах бедствий и инцидентов.

Система отдыха - это пути социализации людей и использования своего свободного времени. Некоторые культуры уделяют значительное внимание занятию людьми спортом, культивируются различные виды активного отдыха. В ряде культур имеет место акцентирование внимания во время отдыха на народные танцы и пение, на посещение зрелищ и т.д..

Модель Хофстида.Большой популярностью пользуется подход к изучению национального в организационной культуре, разработанный Г. Хофстидом и основанный на пяти переменных:

\section{дистанция власти;} индивидуализм, мужественность; стремление избежать неопределенности; долгосрочность ориентации.

Дистанция власти - это степень неравенства между людьми, которую население данной страны считает допустимой или нормальной. При этом низкая степень характеризуется относительным равенством в обществе, а высокая - наоборот.

Индивидуализм - это степень, с которой люди данной страны предпочитают действовать как индивиды, а не как члены какой-то группы. Высокая степень этой переменной предполагает, что человек, находясь в условиях свободных социальных связей в обществе, сам заботится о себе и своих близких в семье, равно как несет за все свои действия полную ответственность. Эта же переменная характеризуется как коллективизм (или низкая степень индивидуализма). В коллективистских обществах людям с детства прививают уважение к группам, к которым они принадлежат, обычно семье, роду, клану или организации. Разницы между членами группы и теми, кто вне ее, не проводится. Члены группы ожидают, что группа защитит их, и будет нести за них ответственность, если они попадут в беду. За это они обязаны платить лояльностью своей группе в течение всей жизни. В индивидуалистских обществах с детства приучают думать о себе в терминах «Я», а не часть «Нас». Ожидается, что, встав однажды на ноги, индивид уже не будет получать защиты от своей группы, и она не будет нести за него ответственность. Поэтому он не должен проявлять сильную лояльность по отношению к группе.

Третья переменная также имеет два полюса: мужественность $u$ женственность, отражающие то, как люди данной культуры относятся к ценностям типа «настойчивость» и «самоуверенность», «высокий уровень работы», «успех и конкуренция», которые ассоциируются 
почти везде в большей мере с ролью мужчины. Эти ценности отличаются от «нежных» ценностей типа «жизненные удобства», «поддержание теплых личных отношений», «забота о слабых и солидарность», ассоциируемых преимущественно с ролью женщины. Речь идет о преобладании в обществе образцов поведения, присущих либо представителям мужского, либо женского пола. Роль женщины отлична от роли мужчины во всех странах, не в «жестких» обществах это различие больше, чем в «нежных».

Четвертая переменная получила, название «стремление избежать неопределенности» и может быть определена как степень, с которой люди данной страны оказывают предпочтение структурированным ситуациям

B, противоположность неструктурированным. Структурированными являются ситуации с ясными и четкими правилами того, как следует себя вести. Эти правила могут быть формализованы, а могут поддерживаться традициями. В странах с высокой степенью стремления избегать неопределенности люди имеют тенденцию проявлять большое волнение и беспокойство, лихорадочность в работе или «авральность». В противоположном случае люди ведут себя и работают более спокойно и систематично. В странах с высокой степенью стремления избегать неопределенности преобладает мнение, что все «не наше и непривычное» представляет опасность. При низкой степени стремления избегать неопределенности все «не свое и непривычное» вызывает познавательное любопытство.

Пятая переменная измеряется долгосрочной или краткосрочной ориентацией в поведении членов общества. Долгосрочная ориентация характеризуется взглядом в будущее и проявляется в стремлении к сбережениям и накоплению, в упорстве и настойчивости в достижении целей. Краткосрочная ориентация характеризуется взглядом в прошлое и настоящее и проявляется через уважение традиций и наследия, через выполнение социальных обязательств.

Модель Лэйн и Дистефано. влияние национального на организационную культуру строится на шести переменных, определяемых как проблемы, с которыми общество сталкивается на протяжении своей истории. Антропологами установлено, что различные общества по-разному справляются с этими проблемами. В модели эти разные пути названы «вариациями в ценностных ориентациях».

Шесть переменных рассматриваемой модели включают:

отночение человека к природе;

ориентацию во времени;

веру о природе человека;

ориентацию на деятельность;

отношения между людьми; ориентациию в пространстве.

Модель предполагает, что каждая из указанных переменных и ее «национальная» вариация имеют непосредственную связь с теми или иными характеристиками и вариациями их состояния в рамках организационной культуры, преобладающей в данном обществе.

Так, вера о природе человека заключается не в понимании того, как один индивид думает о другом, а в том, во что индивид верит, рассматривая возможности человека. Например, можно ли изменить человека или нет. Или являются ли люди изначально плохими, хорошими или теми и другими.

В организации ценностные ориентации в отношении природы человека могут, согласно модели, измеряться через следующие характеристики: система контроля; стиль управления; организационный климат.

Наиболее очевидным, с точки зрения влияния природы человека на организационную эффективность, является система контроля. Ориентация на изначально «плохое» в природе человека служит основой жесткой системы контроля, предполагающей подозрительное отношение к людям. Другие ориентации («нейтральное» и «хорошее») в отношении природы человека будут воспроизводить соответственно более гибкие системы контроля.

Модель Оучи. Широко известная сегодня организация типа «Z», описанная У. Оучи, представляет собой попытку показать, как соединение преимуществ двух достаточно различных культур (японской и американской) «рождает» эффективный вариант культуры американской делового предприятия. Свое исследование У. Оучи построил на сравнительном анализе семи переменных организационной культуры:

$\square$ обязательства предприятия по

отночению ксвоим членам;

$\square \quad$ оценка выполнения работы;
$\square \quad$ планирование карьеры;;
$\square \quad$ система контроля;
$\square \quad$ принятие решений;
$\square \quad$ уровень ответственности;
$\square \quad$ интерес к человеку.

Обязательства по отношению к работникам. Согласно У. Оучи, все три типа предприятия высоко ценят низкий уровень текучести кадров. Увольнения применяются только в безвыходном положении. Однако то, как поддерживается эта культурная ценность, различает эти три типа предприятий. Если в Японии в этих целях чаще используется система пожизненного найма, то американские фирмы традиционно ориентируются на краткосрочный найм, предоставляя индивиду 
свободу выбора. Хотя на практике большинство американских рабочих и служащих строят свою жизненную карьеру, меняя небольшое количество предприятий .

Оценка выполнения работы. Все три типа предприятий проводят эту работу, используя как количественные, так и качественные измерители. Однако временной лаг и его влияние на карьеру имеют различия. Так, на «чисто» американском предприятии ценится быстрое продвижение, основанное на оценке работы с помощью множества количественных измерителей.

Планирование карьеры. Количество выполняемых в процессе прохождения карьеры функций значительно отличает японского и американского менеджеров. «Третий» путь предлагает разнообразить карьеру менеджера в рамках трех — пяти функций.

Система контроля. Без контроля не обходится ни одно предприятие . Однако каждое предприятие решает это по-своему. Если типичное американское предприятие имеет четкую, ясную и достаточно формальную систему отчетности, то для «идеальной» модели предлагается в основном японский подход, когда контроль осуществляется через неформальные и менее структурированные механизмы. Одним из наиболее эффективных механизмов является организационная культура.

Принятие решений. Предпочтение отдается японскому варианту, когда решения в коллективе преприятия принимаются на уровне группы и на консенсусной основе (все в основном согласны и принимают решения к исполнению).

Уровень ответственности. Не в пример преимуществам группового консенсусного решения, модель У. Оучи предлагает для американской фирмы типа «Z» сохранять ответственность на индивидуальном уровне. В этом случае предполагается, что две разные культурные ценности (групповое решение и индивидуальная ответственность) должны уживаться друг с другом. Решается это во многих случаях через механизм участия в управлении, сохраняющий традиционно последнее слово в решении за менеджером. Американская индивидуальность при этом не страдает.

Интерес к человеку. Следуя японскому подходу, У. Оучи предлагает в варианте «Z» рассматривать личность в коллективе предприятия шире, чем просто работника, проявлять интерес к его домашней жизни, увлечениям, вере, желаниям, опасениям и вдохновению. Типично американский подход видеть в индивиде только работника ограничивает возможности управления человеком в коллективе предприятия .

Модель У. Оучи получила на практике применение на ряде японских автомобильных заводов фирм «Тойота» и «Ниссан» в США. В тех случаях, когда предприятия систематически инвестировали в своих работников и их работу на протяжении длительного периода времени, наблюдались постепенные и значительные улучшения.

Основными группами методов поддержания культуры являются следующие.

Объекты, и предметы внимания, оценки, контроля со стороны \менеджеров. Это один из наиболее сильных методов поддержания культуры в коллективе предприятия, так как своими повторяющимися действиями менеджер дает знать работникам, что является важным и что ожидается от них.

Реакиия руководства на критические ситуациии и организационные кризисьл.

В данных ситуациях менеджеры и их подчиненные раскрывают для себя организационную культуру в такой степени, в которой они себе ее и не представляли. Глубина и размах кризиса могут потребовать от предприятия либо усиления существующей культуры, либо введения новых ценностей и норм, меняющих его в определенной мере. Например, в случае резкого сокращения спроса на производимую продукцию у организации есть две альтернативы: уволить часть работников или частично сократить рабочее время при том же числе занятых. На предприятиях, где человек заявлен как ценность «номер один», видимо, примут второй вариант. Такой поступок руководства превратится со временем в организационный фольклор, что несомненно усилит данный аспект культуры в компании.

\section{Моделирование ролей, обучение и тренировка.}

Аспекты организационной культуры усваиваются подчиненным через то, как они должны исполнять свои роли. Менеджеры могут специально встраивать важные «культурные» сигналы в программы обучения и в ежедневную помощь подчиненным по работе. Так, учебный фильм может концентрировать внимание на чистоте рабочего места. Менеджер сам может также демонстрировать подчиненным, например, определенное отношение к клиентам или умение слушать других. Постоянно концентрируя на этих моментах внимание, менеджер помогает, поддерживать определенные аспекты организационной культуры.

Критерии определения вознаграждений $u$
статусов.
Культура в организации может изучаться
через систему наград и привилегий. Последние
обычно привязаны к определенным образцам
поведения и, таким образом, расставляют для
работников приоритеты и указывают на
ценности, имеющие большее значение для


отдельных менеджеров и предприятия в целом. В этом же направлении работает система статусных позиций в коллективе предприятия . Так, распределение привилегий (хороший кабинет» секретарь, автомобиль и т.п.) указывает на роли и поведение, более ценимые предприятием. Вместе с тем, практика свидетельствует о том, что данный метод часто используется не в полной мере и не систематически.

\section{Критерии принятия}

на

работу,продвижения и, увольнения:

Это один из основных способов поддержания культуры в коллективе предприятия . То, из чего исходит предприятие и его руководство, регулируя весь кадровый процесс, становится быстро известно его членам по движению сотрудников внутри предприятия. Критерии кадровых решений могут помочь, а могут и помешать укреплению существующей в коллективе предприятияорга культуры. Так, присущая конвейерному производству текучка кадров на сборочных линиях побудила многие предприятия перейти либо к групповому подходу в работе, либо к переходу на «тележечную» сборку в рамках комплексной бригады.

\section{Организационные символь и обрядность.}

Многие верования и ценности, лежащие в основе культуры предприятия, выражаются не только через легенды и саги, становящиеся частью организационного фольклора, но и через различные ритуалы, обряды, традиции и церемонии. К обрядам относятся стандартные и повторяющиеся мероприятия коллектива, проводимые в установленное время и по специальному поводу для оказания влияния на поведение и понимание работниками организационного окружения. Ритуалы представляют собой систему обрядов. Даже определенные управленческие решения могут становиться организационными обрядами, которые работники интерпретируют как часть организационной культуры. Такие обряды выступают как организованные и спланированные действия, имеющие важное «культурное» значение. Соблюдение ритуалов, обрядов и церемоний усиливает самоопределение

\section{Управление организационной культурой}

Культура коллектива предприятия включает три уровня: символы; ценности и верования; базовые предположения. Возникает вопрос о возможности манипулирования культурой через проведение изменений на каждом из указанных уровней.

Существует позиция, что независимо от той стадии развития, на которой находится предприятие, его высшее руководство может управлять культурой двумя способами . Первый представляет собой как бы видение свыше, которое должно вызывать энтузиазм у большинства членов коллектива предприятия. Руководитель-лидер воодушевляет и претворяет в жизнь базовые ценности предприятия. Это предполагает наличие очевидных и искренних личных обязательств лидера по отношению к ценностям, в которые он верит.

Применение второго способа начинается с другого конца предприятия, с его нижних уровней. В данном случае большое внимание уделяется деталям реальной жизни в коллективе предприятия Менеджеры должны отслеживать по всему предприятию, что у них происходит, стараясь при этом шаг за шагом управлять культурой предприятия.

Известно, что ряд руководителей уверенно придерживается определенных ценностей и верований, но не передает их другим членам коллектива предприятия. В такой ситуации они теряют возможность влиять на культуру предприятия. Менеджеры - «затворники» могут постичь все «технические» тайны управления, но они не могут воздействовать на культуру предприятия, оставаясь «невидимыми». Отсюда следует, что первый способ может реализовываться через публичные заявления, выступления и личный пример, свидетельствующие о последовательном интересе к вводимым ценностям. Руководителям рекомендуется выступать в печати, по радио и по телевидению как можно чаще с проповедованием устанавливаемых ценностей. Последние не должны являться секретом предприятия. Второй способ требует понимания значения культуры в повседневной жизни предприятия. При этом действенными средствами могут быть манипулирование символами и вещами материального мира предприятия, создание и выработка образцов поведения, введение шаг за шагом условий взаимодействия. Управление культурой предполагает возможность через постоянное манипулирование атрибутами поверхностного уровня влиять на подповерхностный уровень вплоть до изменения базовых предположений. Если каждодневные действия менеджеров в коллективе предприятия находятся в соответствии с заявляемыми ими ценностями, то это, безусловно, способствует развитию культуры и ее усилению.

Очевидно, что управление организационной культурой не является простым делом. Ценностные 
ориентации должны быть не только заявлены, но и стать неотъемлемой частью внутренней жизни высшего руководства и передаваться на нижние уровни предприятия во всех своих деталях.

Управляя культурой, следует иметь в виду, что она может служить своего рода «клеем», скрепляющим части предприятия. Вместе с тем необходимо помнить, что если части плохие, то даже лучший в мире «клей» не сделает целое достаточно крепким. Унификация Ценностей и ежедневная работа менеджеров по их «внедрению» в жизнь могут привести предприятие к успеху.

Управление культурой является достаточно длительным процессом, он мало похож на быстрый ремонт неисправностей. Базовые предположения, лежащие глубоко в сознании, верованиях и поведении членов организации, невозможно изменить за короткий срок. Данный процесс предусматривает постоянную социализацию новых членов предприятия, бесконечное выяснение того, во что верят и что ценят в коллективе предприятия , неустанное внимание как к общему абстрактному взгляду на вещи, так и к конкретным деталям быта предприятия, и, наконец, правильного планирования всей этой работы. Рассматриваемые ниже рекомендации могут помочь менеджерам повысить эффективность управления культурой в коллективе предприятия .

Обрашайте особое внимание на нематериальные, внешне не воспринимаемые аспекты организационного окружения. Глубоко укоренившиеся в людях предположения $u$ ценностные ориентации могут требовать длительных и трудных изменений в системе $и$ структуре управления. Культура - это тот путь, который помогает понять организационное «Зазеркалье».

Скептически относитесь $к$ предложениям, призывающим к быстрой трансплантащчи или трансформации культур.

Старайтесь понять значимость важных организационных символов (название компании, логотип, лозунги).

Прислушивайтесь $\quad$ историям, рассказываемым в коллективе предприятия , анализируйте, кто их герои и что эти истории отражают в культуре организации.

Периодически вводите организационные обряды для передачи с их помощьью базовых идеалов и усиления культурь.

Проводите в жизнь абстрактные идеальы непосредственным и прямым образом в своей повседневной деятельности. От менеджера требуется понимание того, каких идеалов он должен придерживаться и какими действиями следует передать эти идеаль вниз по уровням предприятия.

\section{Заключение}

Организационная культура представляет набор наиболее важных предположений, ценностей и символов, разделяемых членами коллектива преприятия. Выделяют различные уровни организационной культуры: поверхностный, подповерхностный, глубинный.

В зависимости от преобладания элементов того или иного уровня выделяют субъективную $u$ объективную культуру в коллективе преприятия. Первая является основой формирования управленческой культуры или стиля руководства.

Организационная культура не является монолитом, а состоит из преобладающей культуры, субкультур групп и контркультур, усиливающих или ослабляющих культуру организации в целом. Сила культуры зависит от маситабов и разделяемости основных его атрибутов членам коллектива предприятия, а также от ясности его приоритетов.

Развитие организационной культуры предполагает ее формирование, поддержание $u$ изменение. Формирование культуры происходит в условиях решения предприятием двух важных проблем: внешней - адаптации и внутренней интеграции. На формирование культуры в коллективе предприятия оказывает влияние культура общества/народа, внутри которого данное предприятие функционирует.

Организационная культура поддерживается тем, чему уделяется внимание, тем, как оценивается и контролируется деятельность членов коллектива предприятия, способами реагирования на критические ситуации - моделированием ролей и обучением персонала, критериями мотивации, а также критериями в кадровой работе. Соблюдение ритуалов, обрядов и традиций также способствует поддержанию организационной культуры.

Изменение организационной культуры является в определенной мере прямо противоположным действием по отношению к ее поддержанию. Изменения в поведении могут привести к изменениям в культуре коллектива предприятия, и наоборот. Возможны три сочетания изменений в поведении и культуре в коллективе предприятия : 1) изменение культуры без изменения поведения; 2) изменение поведения без изменения культуры; 3) изменение поведения и культуры.

Изучение влияния культуры на организациионную эфрективность связано с выбором подхода $u$ переменных. Каждая из существующих моделей влияния культуры использует свой собственный критерий формирования набора организационных переменных; Так, у В. Сате это организационные процессы, у Питера и Уотермана - ценностные ориентации, у Т. Парсонса - функции социальной 
системы, а у Квина и Рорбаха - система конкурирующих ценностей.

Успех в бизнесе предполагает высокую степень совместимости стратегии и культуры в коллективе предприятия. Могут возникать следующие ситуации: игнорируется культура, сильно препятствующая эффективному выполнению выбранной стратегии; система управления подстраивается под существующую в коллективе предприятия культуру; делается попытка изменить культуру в соответствии с выбранной стратегией; стратегия подстраивается под существующую культуру.

Велико влияние национального в организационной культуре. При изучении национального в организационной культуре решаются два вопроса: что надо знать о национальной культуре, чтобы предвидеть ее влияние на культуру предприятия; можно ли «сращивать» лучшее из разных национальных культур в рамках одного коллектива предприятия в целях повышения его эффективности?
При ответе на первый вопрос используются различные модели: Дж. Миллера - системный подход; Г. Хофстида - переменные национальной культуры; Лэйн и Дистефано - переменные национальной культуры и вариации в их изменении, коррелируемые с определенными вариациями организационных переменных. В указанных целях могут также изучаться группы элементов, формирующих состояние данного общества: территория, природа и климат; язык, вера, мораль и право; семья, воспитание и образование; формы социализации жизни людей; способ ведения хозяйства, экономика и бизнес; политика, история и образ правления. Теория «Z» Оучи делает попытку ответа на второй вопрос о синергии разных культур. В модели используется сравнительный анализ семи организационных переменных в преломлении к национальным особенностям и по его результатам формируется культура типа «Z».Данный подход интересен в условиях интернационализации и глобализации бизнеса.

\section{References:}

1. Prokhorov V.T., Maltsev I.M. (2004) Software for screening factors in the active conduct of the experiment. The program for computer №2004611762729. Registered in the Register of computer programs 26.07.2004

2. (2007) The software to solve the problem of non-stationary processes of heat exchange systems of the "Stop - footwear environment", provided the dependence of conductivity on temperature: the certificate of official registration of computer programs № 2008610087 / Mikhailov A. B. Was 09.01.2008. - Registration in the register of computer programs. Application No. 2007614069 (17.10.07).

3. (2009) Software the task of assessing the comfortable stay of man in shoes depending on the changes in heat flux stop time-a certificate of official registration of computer programs №2009613371 / Aspen T. M. Was 26.06.2009. -Registration in the register of computer programs. Application No. 2009611957 (29.04.09).

4. Aspen T. M., et al. (2011) the Certificate of official registration of computer programs №2011611394. Software for calculation of the temperature field of the unsteady heat transfer process in the "Stop - footwear - environment" when exposed to stop low temperatures. Issued by the Russian Agency for patents and trademarks (ROSPATENT) 11.02.2011 g.

5. Aspen T. M., et al. (2011) the Certificate of official registration of computer programs №2011619212. Software description the local unsteady heat transfer in the system of "Stopfootwear-environment" for different climate zones". Issued by the Russian Agency for patents and trademarks (ROSPATENT) 30.11.2011

6. Shrivel I. S., Maltsev I. M., Prokhorov V. T., korablina S. Y., ASP, T. M, Kushnareva I. A. (2015) On a new method for assessing the competence of experts for work in the customs examination // "Science and technology in the modern world: traditions and innovations" proceedings of II All-Russian scientificpractical conference with international participation, 19-20 November 2015: Novosibirsk, 2015. - p. 123-132.

7. Reva D. V., Maltsev I. M., Volkova G. Yu., Prokhorov V. T., S. Yu. Polukhina, Osina T. M. (2015) About the possibilities of new assessment tools to assess the quality of training of highly qualified specialists // the Collection 


\begin{tabular}{l|lr|ll|ll} 
& ISRA (India) & $=\mathbf{1 . 3 4 4}$ & SIS (USA) & $=\mathbf{0 . 9 1 2}$ & ICV (Poland) & $=\mathbf{6 . 6 3 0}$ \\
Impact Factor: & ISI (Dubai, UAE) $=\mathbf{0 . 8 2 9}$ & PUHL (Russia) $=\mathbf{0 . 2 0 7}$ & PIF (India) & $=\mathbf{1 . 9 4 0}$ \\
& GIIF (Australia) & $=\mathbf{0 . 5 6 4}$ & ESJI (KZ) & $=4.102$ & IBI (India) & $=\mathbf{4 . 2 6 0}$ \\
& JIF & $=1.500$ & SJIF (Morocco) & $=2.031$ & & \\
\hline
\end{tabular}

"the role of the modern University technical personnel and modernization of the Russian economy collected works of the IX International scientific.-method. Conf.. Kostroma state technological University" / Kostroma, 2015. P. 226-231.

8. Reva D. V., Shrivel I. S., Prokhorov V. T., Duyun, L. V., Maltsev, I. M., ASP, T. M. (2015) New possibilities of expert estimations as an instrument of evaluation of quality of preparation of experts // the Collection "the role of the modern University technical personnel and modernization of the Russian economy collected works of the IX International scientific.-method. Conf.. Kostroma state technological University" / Kostroma, 2015. -p. 22-28.

9. (2014) The quality revolution: through the ad or through a quality real: monograph V. T. Prokhorov [et al.]; under the General editorship of doctor of technical Sciences, Professor V. T. Prokhorov; VoIP (branch) of DSTU. Novocherkassk: URGU (NPI), 2014. - 384 p. 